\title{
Clinical Approach to the Repeat Breeder Cow Syndrome
}

\author{
Carlos C. Perez-Marin, Laura Molina Moreno \\ and Guillermo Vizuete Calero \\ University of Cordoba, \\ Spain
}

\section{Introduction}

\subsection{Importance of RBC in dairy cattle}

Dairy cattle production requires great intensification, which has been demonstrated to affect negatively on the reproduction. One calf by cow and year is the reproductive objective in these animals. It means that cows must get pregnant after AI, maintain the pregnancy, have parturition after 270 days approx., and wait for a period of 40-50 days to be successfully inseminated again. Nevertheless, this is not always attained and cows must be reinseminated during several consecutive cycles. In this context appears the Repeat Breeder Cow syndrome (RBC), comprising a heterogeneous group of subfertile cows, without anatomical abnormalities nor infections, that exhibit a variety of reproductive disturbances in a consistent pattern during the course of 3 or more consecutive estrous cycles of normal duration (17-25 days). Any of these disturbances may affect the delicate interplay of estrous behavior, hormone patterns, and ovarian dynamics, which in synchrony with the uterine functions finally determines the outcome of mating or artificial insemination (AI) (Bage et al., 2002). Epidemiological studies of RBC prevalence have shown disparate results, ranging from a 5\% described by Ayalon (1984) in Jordan, to a 36\% observed by Zambrano et al. (1982) in Cuba. Nevertheless, considering the great demands on dairy cow production (which ideally requires obtaining a calf per cow per year), RBC has an important impact on dairy cattle economics (Figure 1).

\subsection{Importance of RBC in beef cattle}

Beef cattle reared under extensive system usually have a deficient data record, and then it is difficult to identify this syndrome. In this case cows are considered as RBC when they do not get pregnant after being exposed to bulls during the established reproductive periods. The bull-cow interaction usually ranges from 45 to 90 days, although sometimes it lasts 6 months or it may also be permanent. Few reports on RBC exist in beef cattle (Maurer \& Echternkamp, 1985; Ferreira et al., 2008).

In contrast with dairy cows, to obtain a high reproductive efficiency in beef cattle, it is necessary to get a calving interval of 365 days and an overall calving rate of $95 \%$ (Duffy et al., 2004). The cow should get pregnant around day 85 after parturition. But how many cows 
really get this objective? Studies carried out in US indicate that only between $50-70 \%$ of cows reach this goal. In Spain, the production system presents notable differences with respect to reproductive indexes. Under intensive farming, beef cows usually calve for the first time at 28 months old, while in dairy cows the first parturition occurs at 26 months old. In beef cattle exists a tendency to reduce the calving interval, in contrast with dairy cows.

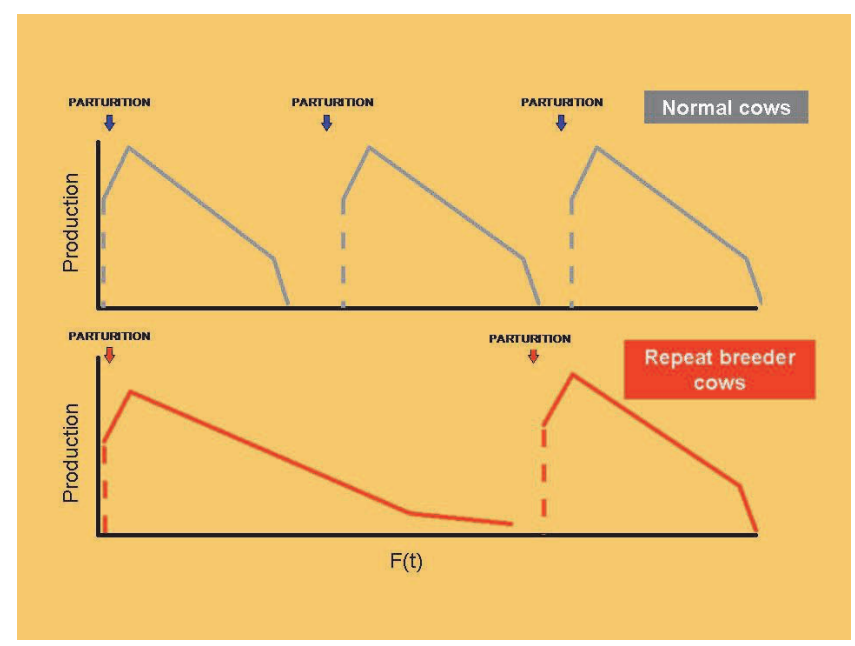

Fig. 1. Evolution of the lactation curves in normal and repeat breeder cows. Note that RBCs have fewer calves per cow and therefore milk yield is also reduced.

The preovulatory follicle size is correlated with fertility in beef cattle, and it has been postulated that the implementation of management to optimize the size of the ovulatory follicle could improve the fertility (Perry \& Perry, 2008). For getting good reproductive results it is recommended to select those animals that:

- calve one alive and health calf per year.

- $\quad$ wean a calf that will reach $60 \%$ of the cow body weight at 7 months old.

- get pregnant after weaning.

- have a good maternal condition.

Then, the reproductive efficiency can be measured throughout the number of weaned calves/number of cows in reproduction $\times 100$. This percentage ranges between $60-70 \%$. The majority of cows that failure to get pregnant (30-40\% of cows in reproduction) has infertility problems during the breeding season, and many of these cows are defined as RBC. This syndrome should be treated in beef cattle farms, since expenses may rise due to the decrease of the number of calves per season and a prolonged breeding season. If beef cows are mated for a long time (for a long season), a low production will be obtained: calves will be less heavy and then its price will be lower, the health management of different ages calves will be more difficult, and the calving interval will be longer. A higher conception rate means that a higher number of calves will be weaned, and then, a higher beef yield is obtained. The costs are the same in pregnant or open cows, but profits are different. It has been reported that dystocia provokes higher economical expenses associated with perinatal mortality of 
calves, veterinary costs and worse reproductive indexes (longer parturition-estrus interval or lower conception rate).

\section{Aethiology of RBC syndrome}

The aethiology of RBC syndrome is unclear and multifactorial. The cow, the bull and several environmental/handling factors are incriminated. All of them are often overlapped and it is difficult to determine the primary origin.

\subsection{Maternal factors involved in RBC syndrome}

Causes provoking repeat estrus in cattle are often related to maternal defects, which used to be at individual-level and make more difficult the clinical assessment and diagnosis. Age, genetic defects, genital tract infections, conformational defects, hormonal disorders, embryo mortality and nutritional defects have been reported. But usually there is no clear aethiology and several concomitant causes often appear, what makes difficult to characterize the problem.

\subsubsection{Influence of maternal age}

It has been widely reported that age impacts negatively on fertility (Hodel et al., 1995), and higher RBC rates have been described in old cows (Hewett, 1968). It is attributed to alterations in hypothalamic or pituitary hormonal levels or to inability of the ovary response (Bullman \& Lamming, 1978). It has also been demonstrated the relationship between old age and low oocytes viability, what explains the fertility decline (Lanman, 1968). Studies in RBCs showed that age and breed affect the FSH and LH levels. FSH was higher in cows with six or more lactations $(1.03 \pm 0.12 \mathrm{ng} / \mathrm{ml})$ and $\mathrm{LH}$ ranged from $1.31 \pm 0.21 \mathrm{ng} / \mathrm{ml}$ in heifers and $2.19 \pm 0.28 \mathrm{ng} / \mathrm{ml}$ in cows after three calves, falling to $0.94 \pm 025 \mathrm{ng} / \mathrm{ml}$ in six or more calves (Santana et al. 2000). It is supported that fertility in dairy cattle improves after the 1st or 2nd parturition, and decreases from the 4th or 5th, but it should be taken into account the time required for uterine involution or problems associated to puerperium (Dominguez, 1989).

\subsubsection{Genetic factors in repeat breeder cows}

Individuals inherit their parent's genetic merit, and then chromosomal or genetic abnormalities of parent, or those that occurred during the differentiation process may compromise fertility. RBC syndrome has been described in cows with chromosomal abnormalities as translocation $1 / 29$ or trisomy X (Roberts, 1971; Lafi \& Kaneene, 1988; Bruyas et al., 1993). A study regarding Robertsonian translocation 1/29 in cattle (Rodriguez et al., 2000) informed that cows diagnosed with this chromosomal defect were classified as RBC. Few embryos (less than 10\%) exhibit chromosomal or genetic abnormalities, and are usually associated with high inbreeding or aged gametes. Humblot (1986) observed higher RBC rate in Holstein and Charolais breeds than in Norman or Frisian breeds, considering breed as a risk factor for this syndrome.

The utilization of bulls to produce bigger calves could be considered as a genetic- or management-based problem when dystocia or postpartum disease appear, and metritis, infertility or repeat estrus are developed. 


\subsubsection{Uterine infection and repeat estrous cycles}

The uterine environment promotes the normal embryonic development. So, any disorder compromises the survival of the embryo and induces the RBC syndrome. Some authors have observed a correlation between repeat estrus and endometrial abnormalities (Roine \& Saloniemi, 1971; Francos, 1979; Santana et al., 1998b). In fact, reproductive failure appears after metritis, and Francos (1979) observed that from 3.5 to $5.7 \%$ of cows with metritis had repeat estrus. Arguably, uterine infections (specific and nonspecific) will adversely affect the reproductive indexes by enlargement of the uterine and cervical postpartum involution, by alteration of follicular development (Lewis, 1997), and by increased embryo mortality and repeat estrus rates (Santana et al., 1998).

Subclinical endometritis should be considered when pregnancy failure or repeat estrus is observed. However, clinical signs are difficult to detect; it is not easy to do the diagnoses by rectal palpation and the bacteriological analysis of cervical mucus does not reflect the endometrium status. Endometrial biopsies and uterine microbiological culture can enhance the diagnosis. Leukocyte infiltration in moderate degree with lymphocytes, neutrophils, plasmocits, eosinophils and macrophages are histopathological findings that have been reported in the endometrium of RBCs

Many authors have identified the germs located in the reproductive tract of RBCs:

- $\quad$ Sagartz y Hardenbrook (1971): Stafilococos, Corinebacterium.

- Hartigan et al. (1972): Stafilococos aureus, Gram+, Streptococos $\beta$ haemolitic, Streptococos microaerofiles.

- Murthy et al. (1974): Pseudomonas, Aerobacter sp, Klebsiella sp, Paracolobactrum sp, Proteus sp, Micrococos sp, Stafilococos sp, Corinebacterium sp, Bacillus sp.

- Palangala et al. (1978): Streptococos sp, Escherichia coli, Bacillus sp, Corynebacterium $\mathrm{sp}$; others less frequent as Proteus sp, Klebsiella sp, Pasteurella sp, Neiseria sp, Branhamella sp, Actinobacter sp, Haemophilus sp, Kurthia sp.

- Harvey (1993): Nocardia

- Singla et al., (1993): Stafilococos aureus, Escherichia coli, Klebsiella pneumoniae

- Vasconcelos et al. (1995): Streptococos sp, Enterobacterias, Stafilococos, Yeast.

- Santana et al. (1998a): Escherichia coli, Stafilococos non-haemolitc sp, Acinetobacter sp, Streptococos $\beta$-haemolitic, Enterobacter cloacae.

Barbato et al. (1994) studied histopathological changes in repeat breeder zebus, describing focal chronic endometritis, adenomyosis, endometrial hyperplasia, glandular hyperplasia of the "rete ovarii", hyperplasia of the ovarian serous membrane, oophoritis and granulosa cells tumour. It was concluded that uterine infections are the main causes of RBC in zebus.

\subsubsection{Anatomical defects of the genital tract}

The reproductive tract of cow provides a suitable environment for oocyte growth, as well as for sperm transport, fertilization and implantation. Uterus is a suitable habitat for the embryonic and fetal development. A complex communication between hormones, proteins, etc. will be necessary for obtaining reproductive success. Anatomical or functional changes of these structures can drive to gestational failure and infertility. Therefore, it is essential to carry out a proper reproductive assessment for discarding animals with congenital or acquired defects. 
Oviductal abnormalities, that complicate and frequently inhibit the reproduction, are present in $6-15 \%$ of adult cows and can reach up to $80 \%$ in those with a history of infertility or repeat breeding. Adhesions between the ovary, fallopian tubes or ovarian bursa, unilateral or bilateral obstructions, moderate degree of hydrosalpinx and inflammation (perisalpingitis, peritonitis) have been described in RBC syndrome (Figure 2). López-Gatius (1995), based on previous studies, proposes the use of intraperitoneal insemination in RBC to avoid the detrimental effect of uterine diseases on the sperm transit.

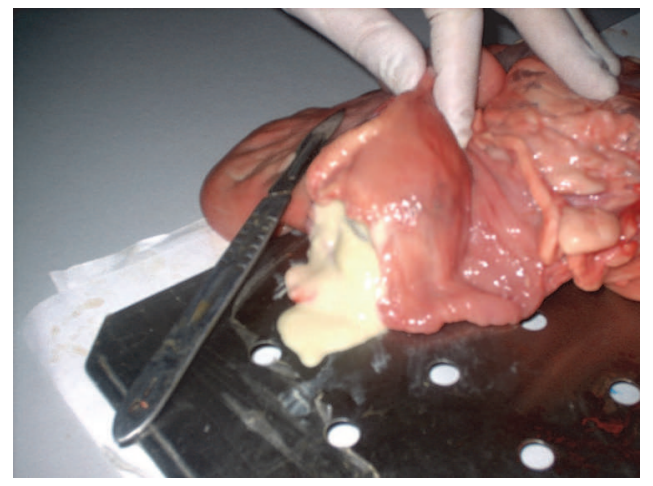

Fig. 2. Piosalpingitis observed at slaughterhouse.

Acquired uterine alterations, as metritis, are critical to the resumption of the normal cyclicity during postpartum period, provoking RBCs (Shresta et al., 2004). Other non-infectious abnormalities, as uterine degeneration and neoplasia, could also be involved in this syndrome, although their incidence is low.

Cervix is a defensive barrier and a sperm reservoir, and may undergo structural changes associated with inflammation. Cervical traumatic stenosis and obstruction, prolapse of cervical rings, adhesions or functional incompetence can be detected associated with RBCs.

Vagina acts as receptacle for semen and is one of the uterine defensive barrier. Infectious disorders alter vaginal $\mathrm{pH}$ and bacterial flora, allowing the infection and reducing the sperm vitality. Congenital anomalies, conformation defects (urovagina and pneumovagina) and infections (vaginitis) could be diagnosed. Vulvitis or vestibulitis may also modify the normal reproductive function.

\subsubsection{Hormonal dysfunctions}

Following are showed some alterations that affect the reproductive hormonal function and produce RBCs, although their diagnosis is usually difficult and uncertain. Perez-Marín \& España (2007) reported hormonal dysfunctions found in RBCs in Spanish farms (Table 1).

Hypofunctional CL provokes a decrease of progesterone and affects negatively the fertility. Perez-Marín \& España (2007) reported that hypofunctional CL was diagnosed in a 17,3\% of RBCs, and Gonzalez-Stagnaro et al. (1993) affirm that this pathology appears in $23,7 \%$ of cows. CLs are small and poorly developed, with low progesterone production and LH peak asynchrony. Therefore, inadequate uterine environment is formed and this increases the abnormalities and the loss of embryos. As Kimura et al. (1987) suggested, a delayed increase 
in progesterone levels may indicate late or insufficient corpus luteum formation following ovulation or short luteal phase. Shelton (1997) argues that luteal inadequacy, due to a diminished response to circulating luteotrophic hormones, may contribute to embryo mortality in subfertile cows. A delayed and diminished post-ovulation progesterone curve has been associated with low conception rates in cattle, and a low progesterone curve has been shown to be related to significantly reduced production of interferon-tau by bovine embryos recovered on Day 16 of pregnancy (Figure 3).

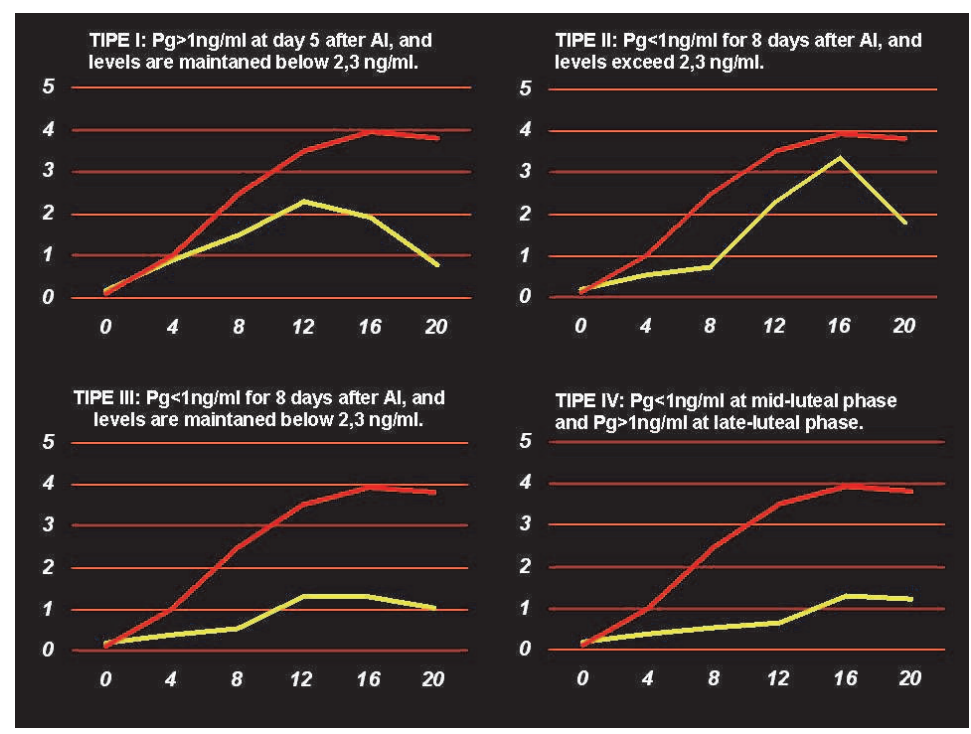

Fig. 3. Luteal phase deficiency in cow. Red line indicates normal progesterone levels, and yellow line indicates the progesterone level in cows with luteal hypofunction.

Suprabasal progesterone level around estrus has been described in RBCs (Duchens et al., 1995; Bage et al., 1997; Perez-Marín \& España, 2007). It is associated with low gonadotrophin levels and with incomplete luteal regression after luteolysis, which prolongs the follicular growth and damages the oocyte. A longer estrus-ovulation interval usually appears and premature insemination is then carried out. Duchens et al. $(1995,1996)$ have experimentally induced this pathology using retard release progesterone. It has been informed that these levels reduce the number of blastomeres around day 3, accelerate the zygote progress though the oviduct and affect negatively the fertility.

Anovulation has been reported in $2-16 \%$ of RBCs and it is characterized by prolonged basal progesterone after estrus (Gonzalez-Stagnaro et al., 1993; Perez-Marín \& España, 2007). The LH release pattern is modified and follicle does not get the stimulus for ovulation to occur. The follicle continues growing and releases estradiol, which induces the formation of persistent follicles and delayed ovulation. Also, defective follicle recruitment during the middle- and late-luteal phases has been suggested as a cause of anovulation. An abnormal hormone environment may promote continuous development in the dominant follicle, impairing follicular function and oocyte quality, and thus reducing fertility (Odde, 1990; Stock \& Fortune, 1993). 
Irregular and delayed ovulations have been associated with asynchrony between estrus and ovulation (Duchens et al., 1994), asynchrony of LH peak and ovulation (Lee et al., 1983), or incapacity for LH release (Duchens et al., 1995). The LH peak characteristics are altered in RBCs and estrous signs are less intense than in normal cows. As described above, suprabasal progesterone levels can be involved.

\begin{tabular}{|c|c|c|c|c|c|}
\hline RBC & Diagnosis & $\mathbf{n}$ & $\%$ & $\begin{array}{l}\text { Progester- } \\
\text { one on } \\
\text { day } 0\end{array}$ & $\begin{array}{c}\text { Pre- } \\
\text { ovulatory } \\
\text { follicle size }\end{array}$ \\
\hline Pregnant & & 9 & 24,32 & $0,37 \pm 0,20$ & $1,79 \pm 0,33$ \\
\hline \multicolumn{6}{|l|}{$\begin{array}{l}\text { Reproductive } \\
\text { failure }\end{array}$} \\
\hline & Prolonged luteal phase & 3 & 8,11 & $0,34 \pm 0,10$ & $1,60 \pm 0,31$ \\
\hline & $\begin{array}{l}\text { Ovarian cysts and } \\
\text { anoestrus }\end{array}$ & 2 & 5,41 & $0,18 \pm 0,10$ & $1,33 \pm 0,04$ \\
\hline & $\begin{array}{l}\text { Luteal dysfunction type } \\
\text { II }\end{array}$ & 1 & 2,70 & 0,12 & 1,65 \\
\hline & AI mis-timmed & 1 & 2,69 & 2,47 & --- \\
\hline & $\begin{array}{l}\text { Suprabasal levels of } \\
\text { progesterone }\end{array}$ & 1 & 2,71 & 1,78 & 3,2 \\
\hline & Late ovulation & 2 & 5,41 & $0,53 \pm 0,01$ & $2,03 \pm 0,25$ \\
\hline & Anovulation & 1 & 2,70 & 0,49 & 2,15 \\
\hline & $\begin{array}{l}\text { Luteal dysfunction type } \\
\text { II }\end{array}$ & 3 & 8,11 & $0,24 \pm 0,16$ & $1,40 \pm 0,26$ \\
\hline & $\begin{array}{l}\text { WITHOUT diagnosed } \\
\text { aethiology }\end{array}$ & 14 & 37,84 & $0,28 \pm 0,23$ & $1,92 \pm 0,32$ \\
\hline
\end{tabular}

Table 1. Endocrine dysfunctions and reproductive management defects detected in RBC in Spain (Pérez-Marín \& España, 2007).

\subsubsection{Early Embryonic Death (EED) causes RBC syndrome}

The bovine embryo releases a substance of trophoblastic origin (interferon tau) into the uterus around day 16-18 that prevents luteolysis (Sheldon, 1997; Kerbler et al., 1997) and maintains the luteal function and pregnancy. EED has been attributed to irregular LH and progesterone profiles that induce failures in the maintenance of CL (Swanson \& Young, 1990). EED is associated with poor quality of gametes and zygotes, uterine alterations, hormonal imbalances and defects in the immunitary mechanisms (Bruyas et al., 1993). The EED occurs between days 8 and 16 post-mating (Diskin \& Sreenan, 1980), before cow returns to estrus. As a result, no variation at interestrus interval is observed and clinicians cannot differentiate between embryonic resorption and other pregnancy failures. The incidence of EED is highly variable, from 10.6 to $39.7 \%$.

Kimura et al. (1987) consider that EED and fertilization failure are recurrent causes of RBC, and genetic, environmental and endocrine influences are risk factors involved. De la Fuente et al. (1988) observed a lower embryo production in RBCs. In this study, FSH-p was administrated as superovulatory treatment and the good results suggested that non-ovarian factors (hormonal, uterine...) directly influence the reproductive failure in RBCs. Results 
obtained after embryo transfer in RBC suggest that uterine environment is the most important factor in the EED, reporting abnormal concentrations of ions and proteins in the uterus. Intrinsic embryo factors are also related with this syndrome. Linares (1982) observed that blastocysts collected in RBCs had more abnormalities than those of control cows $(3: 1)$, and the oocyte collection rate was also lower, possibly due to a degenerative process initiated after fertilization. It was determined that the reduction of embryo viability could be associated with the reduction of nutrients exchange capacity and other regulatory substances. They could disrupt the process of cell differentiation, initiate degenerative processes, and slightly reduce the number of cilliar cells in the endometrium. High and early endometrial progesterone receptors have been detected 3 days after estrus in RBC that suggest hormonal and cellular changes in the uterus (Almeida et al., 1987, 1995).

Abnormal embryonic development by hormonal asynchrony during estrus and metaestrus have been involved in the RBC syndrome. Inadequate levels of estrogen and abnormal interactions with gonadotrophins injure the oocyte maturation, resulting in abnormal embryonic development. The altered hormonal pattern in RBCs could cause the incompetence of oocytes that will suffer abnormal embryonic development (Gustafsson et al., 1986; Albihn et al., 1991). However, other authors consider that the majority of embryonic abnormalities occur during the way through the oviducts, although those abnormalities are not evident until 6-7 days post-AI (i.e. in blastocyst stage). As oocytes of RBCs are competent to reach the blastocyst stage and to continue the development, embryo production (IVM-IVF-IVC-ET) could improve the reproductive success in these animals.

EED has usually no effect on the normal length of the estrous cycle. In occasions, anamnesis in RBC shows normal estrous cycle and fertilization rate, and the "apparent infertility" is due to earlier embryo mortality (day 7). No significant differences have been detected in these animals regarding estrus duration, ovulation time and the incidence of anovulation or silent estrus (Linares et al., 1984).

\subsubsection{Inadequate follicular growth}

It has also been proposed that failure of pregnancy in RBCs could be associated to dysfunction in the recruitment of large follicles during the second half of the estrous cycle, resulting in absent or abnormal ovulation, or early cow-embryo asynchrony, occurring EED and RBC. The critical period in the follicular recruitment occurs as from 10 days before ovulation (Staigmiller \& England, 1982; Thibier et al., 1985). Dominant follicle continues its growth when progesterone levels are subluteal (or suprabasal), in which case follicular function is compromised and oocyte quality is reduced, affecting negatively the fertility (Odde, 1990; Stock \& Fortune, 1993).

\subsubsection{Effect of nutrition on RBC syndrome}

The importance of nutrition in all vital processes is indisputable, and the qualitative and quantitative differences in the ration in dairy cattle may cause reproductive dysfunctions (Roberts, 1971; Casida, 1961; Lagneau, 1981; Pedroso \& Roller, 1996; Dovensky et al., 1996). Nutritional deficiency and increment of services per cow are linked, because the decrease in food intake, weight and body condition causes endocrine imbalances that affect fertility and other organs or systems. The mentioned nutritional deficiency can also affect the postpartum period, causing delay in the uterine involution and increasing the number of 
open days. McClure (1995) reported that reproductive disorders could occur at 3 levels: the synthesis and release of LH from hypothalamus, at ovarian function, or at ovulation, fertilization and development of the fertilized egg, embryo and fetus.

Homeostasis of nutritional elements can be maintained through correct animal diet (deficit or excess depends on the production status). Nutritional variations may be due to an excess or deficiency of certain elements or imbalances of their concentrations in diet, and provoke alterations in their absorption or utilization. Nutritional deficiencies are more significant in high production animals, as occur in dairy cattle. In the 70's, Payne et al. (1973) developed the theory of metabolic profiles, which aimed to monitor the metabolic status and health of the herd.

\subsection{Bull factors involved in the RBC syndrome}

Factors related to the bull and sperm quality must also be taken into account when RBCs are evaluated. It is essential to evaluate the sperm function in both natural mating and AI. Frozen semen straws should be carefully stored and managed. Repeat pregnancy failure could be linked to the mentioned bull factors, in which estrus is repeated and interestrus interval has normal duration. Some relevant aspects are mentioned below.

\subsubsection{Influence of bull fertility and semen quality on repeat breeding}

Optimal bull fertility (by natural breeding or AI) is necessary to achieve high pregnancy rate and normal calving interval. Semen doses for AI must contain at least 6 million of motile sperm after thawing, and fertility drops if sperm concentration is reduced (Foote \& Parks, 1993). Currently, frozen semen doses are packed with 15-25 million of motile sperm prefreezing, because around $50 \%$ of spermatozoa recover motility after thawing. However, despite semen doses may fulfill all requirements, there are donors of sperm with erratic fertility. Eid et al. (1994) found that embryos formed from high fertile bulls reached earlier the $S$ phase of DNA synthesis and the 2-cell phase, showing high blastocyst viability. Embryos from low fertile bulls showed a longer G2 phase associated with sperm DNA damage or DNA replication failure during the S3 phase (Eid et al., 1995). The strict selection of semen donors based on the semen quality after thawing and sexual behavior, among other variables, has reduced defects in bulls used for the creation of frozen semen banks.

At natural breeding, it is necessary to assess the reproductive performance of the bulls at least twice a year, carrying out semen assessment (macroscopic and microscopic) and physical evaluations. It is also interesting to evaluate libido and the sexual behavioral pattern for mating to diagnose reproductive failures in bulls. On the other hand, it is essential to maintain an appropriate male:female ratio for mating. For guaranteeing optimal ejaculates, bulls should do 10 mating throughout a week.

\subsubsection{Site of semen deposition and estrus return}

Sperm that has just been ejaculated into the vagina by the bull or placed into the uterus by the inseminator should reach the oviducts, where fertilization occurs. Sperm begins its upward through the tubular tract of the female and reaches, within minutes, the fallopian tubes to find the oocyte. It has been reported that the utero-tubal isthmus acts as a reservoir 
of sperm, making these cells to go up gradually towards the ampulla, preventing polyspermy and ensuring that sperm finds the oocyte into the oviduct (Hunter, 2002). The interaction of sperm with the reproductive female tract results in a drastic decline of spermatozoa. Thus, the female reproductive tract may alter the mechanism of sperm transport and induces infertility. In addition, defective inseminations (e.g. deposition of semen at the entrance of the cervix) may provoke RBC and affect negatively the fertility rates. Higher conception rates are obtained when sperm is deposited into the uterus (Gwazdauskas et al., 1986), but the incidence of uterine disease in RBCs ranges between 36 and $89 \%$ (Ellington \& Schlafer, 1993). It has been suggested that intraperitoneal insemination may be an alternative to uterine insemination (López-Gatius, 1995) in cows with uterine diseases.

\subsubsection{Time of semen deposition}

Time of semen deposition is closely related with the detection of estrus and with all those factors that may affect the preovulatory LH. Other cows or a bull mounting the cow are recognized as signs of the cow heat. This behavior could last between 13-17 $\mathrm{h}$. on average, and ovulation will take place approximately $30 \mathrm{~h}$. after starting the heat. It must be ensured that semen is deposited in the female tract as close as possible to that time. The AM/PM rule is the most common practice in dairy cattle farms: it consists of making insemination at morning if the cow was in heat the previous evening, or being inseminated in the afternoon if heat was detected in the morning. If the technician palpates ovaries before insemination and considers that the follicle texture is far to ovulation, double insemination is recommended separated by 12 hours. Similar pregnancy rates have been reported after one or two inseminations per day (Wahome et al., 1985). As noted above, semen is normally deposited into the uterus, and the uterine environment will be adequate depending on the stage of the estrous cycle. This is one of the most common problems in RBCs, in which any change of $\mathrm{pH}$, endometrial stroma and glands, endometrial flora, etc. could affect the reproduction (Ohtani \& Okuda, 1995).

\subsection{Environmental and management factors affecting the RBC syndrome}

These factors are very miscellaneous. Hewett (1968) suggests a correlation between RBC and the following variables: lactational stress, size of livestock (the number of cows with repeat estrus increases in bigger livestocks), milk yield or calving season (a greater number of RBCs are detected in autumn calves). Similarly, Gustafsson \& Emmanuelson (2000) considered as risk factors for RBC syndrome the first lactation, dystocia or calving difficulties, the first insemination at winter, reproductive disorders before the first insemination, high milk yield or clinical history of repeat estrus. Therefore, environmental and animal management factors should be considered in order to reduce the incidence of RBC syndrome.

\subsubsection{Season}

Barlett et al. (1986) reported that there is no association between breeding season and RBC syndrome. However, ovarian follicular growth and development of the dominant follicle can be altered during the summer months, and heat stress exerts a depressant effect on the 
endocrine mechanisms (reduced intensity of estrus, decreased preovulatory LH peak, etc) and/or the embryo, reducing the fertility.

However, other authors (Gonzalez, 1981) observed that higher progesterone concentrations was present in fertile and anestrus females during warm periods, attributing it to increased activity of the CL or the adrenals by heat stress. Photoperiod length and temperature variations are linked to the season, and could influence the endocrine regulation of the estrous cycle. Other factors as body condition at calving, feeding level and calvinginsemination interval are also season-related, and can be modified through management practices (Fulkerson \& Dickens, 1985). GnRH-based treatments used in RBCs reveal a marked seasonal response, and it has been demonstrated that RBCs and infertility increase during summer (hot) months (BonDurant et al., 1991; Gonzalez-Stagnaro et al., 1993).

\subsubsection{Estrus detection}

The poor heat detection is one of the main causes of RBC and infertility in cattle (Lafi \& Kaneene, 1988; Perez-Marin \& España, 2007). Computer simulation models have been implemented to improve the estrus detection and it has been showed that they increase the frequency of heat detection and reduce the services/conception and days open (Bailie, 1982). Reproductive failure may be observed after mis-timed inseminations or in cows without evident estrus. Pregnant cows could show estrous signs and they could be inseminated. This intrauterine procedure could induce early or late embryonic death, or abortion in pregnant cows. Between 3 and $10 \%$ of pregnant cows can be mounted by other cows, and early pregnancy diagnosis reduces these mis-timed insemination. Some authors recommend making intracervical insemination if reproductive status of cows in heat is doubtful (LopezGatius \& Camón-Urgel, 1991; Bullman \& Lamming, 1978).

\subsubsection{Hygiene at artificial insemination and parturition}

It is essential to act carefully and prevent infections at reproductive tract. During artificial insemination, the catheter is inserted into the uterus, and may act as a disseminator of pathogenic bacteria that alter the normal uterine environment and provoke subacute, acute or chronic infectious diseases, with harmful effects on reproduction.

On the other hand, is essential to care the peripartum period. In fact, many authors consider this period, and particularly the postpartum period, the most critical in the reproductive activity, observing that animals showing problems during this period are finally RBCs (Erb et al., 1985).

\subsubsection{Stress}

RBCs have a higher predisposition to be stressed (Bage, 2002), as evidenced by the increased capacity to produce cortisol from adrenal glands after induced stress. Adrenal progesterone in induced-stress cows reaches suprabasal levels. Thus, stress can be considered as a potential factor in the RBC syndrome.

Heat is one of the stressful causes in cattle. It has been shown that heat-stressed cows reduce the duration and intensity of estrus, and alter hormone levels by increasing circulating 
corticosteroids and by reducing the concentration of progesterone. Uterine environment is altered and viability of the pre-implanted embryo is reduced. It is recommended to use sprinklers, fans cooling, etc., to handle this stress (Ferreira et al., 2011).

\section{Diagnosis of RBC syndrome}

It is necessary to diagnose the aethiology of reproductive failures in cows having an apparently normal clinical history and then, reduce the economical impact. However, although many diagnostic tools are available, it is usually difficult to get a correct diagnostic because sometimes it is unprofitable.

First of all, a complete clinical history should be obtained at herd and individual level. Age, parity, milk yield, previous diseases, reproductive indexes, estrous cycles characteristics, insemination schedule, bulls, estrus detection, hormones, food and farm hygiene should be registered. Now, anatomy, morphology and function of cows should be inspected. The reproductive status of animals must be according to their production. Sexual behavior must be evaluated to detect disorders, as muscle or claw lameness. Similarly, it is necessary to examine the behavior of bull and bull-cow interactions when natural breeding is carried out. Vulva, vagina, cervix, uterus, fallopian tubes and ovaries must be evaluated to diagnoses reproductive defects.

\subsection{External inspection and vaginal evaluation}

External inspection can identify congenital or acquired anatomical defects as pneumovagina, vulvar defects, tumors or injuries. The anatomy of the area, secretions around vulva or tail, and vulvar and vaginal coloration should be evaluated.

In vaginal palpation, vulvar and vestibular functionality are evaluated though the pressure of these structures around the clinician's hand. It also assesses the presence of adhesions, abnormal structures and cervical defects. The vaginal contents should be inspected to detect urine (if urovagina), pus (if endometritis, vaginitis ...), blood (post-ovulation or some diseases) or clear and clean mucus (associated with heat) (Figure 4).

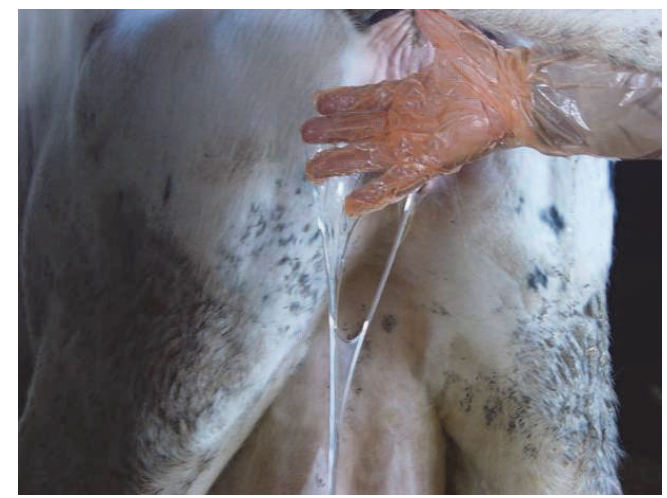

Fig. 4. Transparent and abundant vaginal mucus indicates optimal heat and good uterine environment. 
Vaginoscopy is helpful to visualize the vaginal cavity and cervix. Feces are removed from rectum before the perineal area, vestibule and clitoral fossa were cleaned and finally dried. The speculum -which must be clean, dry, sterile, and lubricated- is inserted in direction of the pelvic canal. Once crossed the vestibule, the negative pressure inside allows air to penetrate. Hyperemia may result in 30-60 sec, which hampers the assessment of the vaginal mucosa coloration. The vestibule acts as a defensive barrier of the female genital tract, and hinders the entry of the speculum. If this does not occurs, dysfunctions can be present (e.g. in pneumovagina). Similarly, if material is accumulated into the vagina, speculum helps to localize its origin.

The examination of internal organs (uterus, oviducts and ovaries) demands other techniques, as manual palpation and ultrasound.

\subsection{Rectal palpation in cow}

Rectal palpation is a widely used diagnostic method in cattle with high accuracy, easy to be implemented and at low cost in comparison with other sophisticated techniques. Plastic gloves are lubricated and then feces are withdrawn. Air should not be present into the rectum to get a more relaxed mucosa and easily manipulate the structures beneath. The cervix is presented as a solid structure, tubular, fibrous, with 3-4 folds projected inside and localized on pelvis floor in normal non-pregnant cows. It is cylindrical, with a length of 5-10 $\mathrm{cm}$ and a diameter of $1,5-7,0 \mathrm{~cm}$. Cranially the uterus can be palpated. At heat, uterus is turgid, erect and coiled. However, it is soft and flaccid during luteal phase and palpation is a bit more difficult; it is a consequence of the progesterone action, released from CL. Palpation helps to diagnose anomalies such as uterine infections.

After that, it is interesting to palpate the ovaries. They are located ventrolaterally to the pelvis floor, and sometimes placed under the bone. During anestrus, ovary size ranges from 2 to $3 \mathrm{~cm}$ approximately. Follicles (at different stages of growth) and CLs (hemorrhagic, mature or/and albicans) are developed at the ovaries and its size could suggest some diseases.

\subsection{Ultrasonography (US)}

The first description of cattle pregnancy by real-time ultrasound was conducted by Chaffeux et al. (1982). Later, Pierson \& Ginther (1984) showed ultrasound images of normal ovarian structures in superovulated heifers. Also Reeves et al. (1984) described the echogenic cystic CL. More recently, ultrasound technology has been used for developing more effective superovulation, embryo collection and recipient's synchronization. Foetal sex can be determined by ultrasonography (US) from day 50 onward, emphasizing that it can be accurately established around day 60 of pregnancy. Ultrasonographic anatomy of foetal sex organs, from genital tubercle (GT) to fully developed organs, has been extensively described in their entire progression. The external genitalia are initially formed on the caudoventral surface of the abdominal wall, between the hind limbs. These primordial structures are seen as poorly defined elevations and they constitute the GT, the urogenital fold and the genital swelling, which are developed into the male or female gonads. In males, the GT becomes elongated to form penis, the urogenital folds enclose the penis to form the prepuce and the genital swelling become enlarged to develop into the scrotum. In females, the GT forms the 
clitoris, the genital swellings completely disappear and the urogenital folds develop to enclose the GT, forming the labia (Quintela et al., 2011).

Other ultrasound application is the aspiration of oocytes, or "ovum pick-up" (OPU) (Pieterse et al., 1988). It is less traumatic and invasive than laparoscopy, does not affect the ovarian activity and can be given many other utilities. Among them the treatment of RBCs syndrome is the most notable, since it allows collecting oocytes that will be in vitro maturated, fertilized and cultured.

Transrectal ultrasound diagnosis has improved our ability to assess the reproductive organs in cattle and to follow the dynamic interactions between ovarian follicular cohorts. Even 2-3 $\mathrm{mm}$ follicles can be seen, quantified and sequentially monitored, allowing the development of superovulation regimens, an essential practice for the embryo transfer industry. US practical uses include routine assessment of follicular and luteal development, and differential diagnosis of cystic ovaries, ovarian abscesses and tumors, which can be considered factors associated with RBC syndrome. US helps to evaluate the uterus by detecting changes in shape and echotexture related with circulating hormone concentrations during the estrous cycle, and thereby detecting hormonal imbalances. It is also useful for detecting pathological conditions such as metritis, pyometra, maceration or mummification, and it is an important tool for diagnosing ovarian cystic disease (Rajamahendran, 1994).

\subsection{Hormonal function tests}

Sex hormones, neurotransmitters and other substances are involved in the regulation of the sexual cycle in cow. Synthesis, release, actuation or interaction imbalance of these substances could be related to reproductive alterations as repeat estrus and reduced fertility. Progesterone can be considered as a sensor of the reproductive capacity, both for its information about the estrous cycle and for its easy determination. Progesterone assay is an objective and accurate test to evaluate the ovarian function and to diagnose certain diseases that otherwise could not be correctly determined, such as delayed ovulation, persistent luteal activity, ovarian cysts or suprabasal progesterone levels (Lamming et al., 1989; Waldmann et al., 2000). When cows are in estrus, this assessment could confirm that the hormonal environment is within the correct hormonal framework. Then, if progesterone is measured around day 19-21 after AI, it could be an effective method to detect females with pregnancy failure. Radioimmunoassay (RIA) and enzyme immunoassay (ELISA) are the usual analytical techniques for determining steroids in biological fluids.

\subsection{Oviductal patency}

The determination of oviductal permeability is interesting, although it is difficult to carry out. An injection of $500 \mathrm{ml}$ of sterile solution containing $30 \mathrm{gr}$ of starch has been described by Kessy \& Noakes (1979). It is intraperitoneally injected and starch reaches the oviduct and descends to the cervical mucus if the fallopian tubes are permeable. It takes about 12 hours to arrive at the cervical mucus, where it will remain between 2 and 4 days. A sample of mucus is collected, stained with lugol and observed under the microscope. Other procedure to study the oviducts individually is infusing phenolsulphonfthalein into the uterine horn. A Foley catheter is inserted through the uterus and the balloon is inflated on the end of the horn before dye is infused. If the oviduct is normal, the dye will cross it, reach the abdominal cavity, and is eliminated by urine. Bladder is catheterized 20 minutes later and 
urine turns to reddish if oviduct is normal. After 4 hours, the test can be repeated in the other oviduct (Figure 5).

Another diagnostic technique to check the oviductal patency is collecting oocytes or embryos, either with or without superovulation treatments. In addition, if they are collected, it is possible to transfer them to cows without reproductive problems, in which case it also becomes a therapeutic tool to overcome this syndrome.

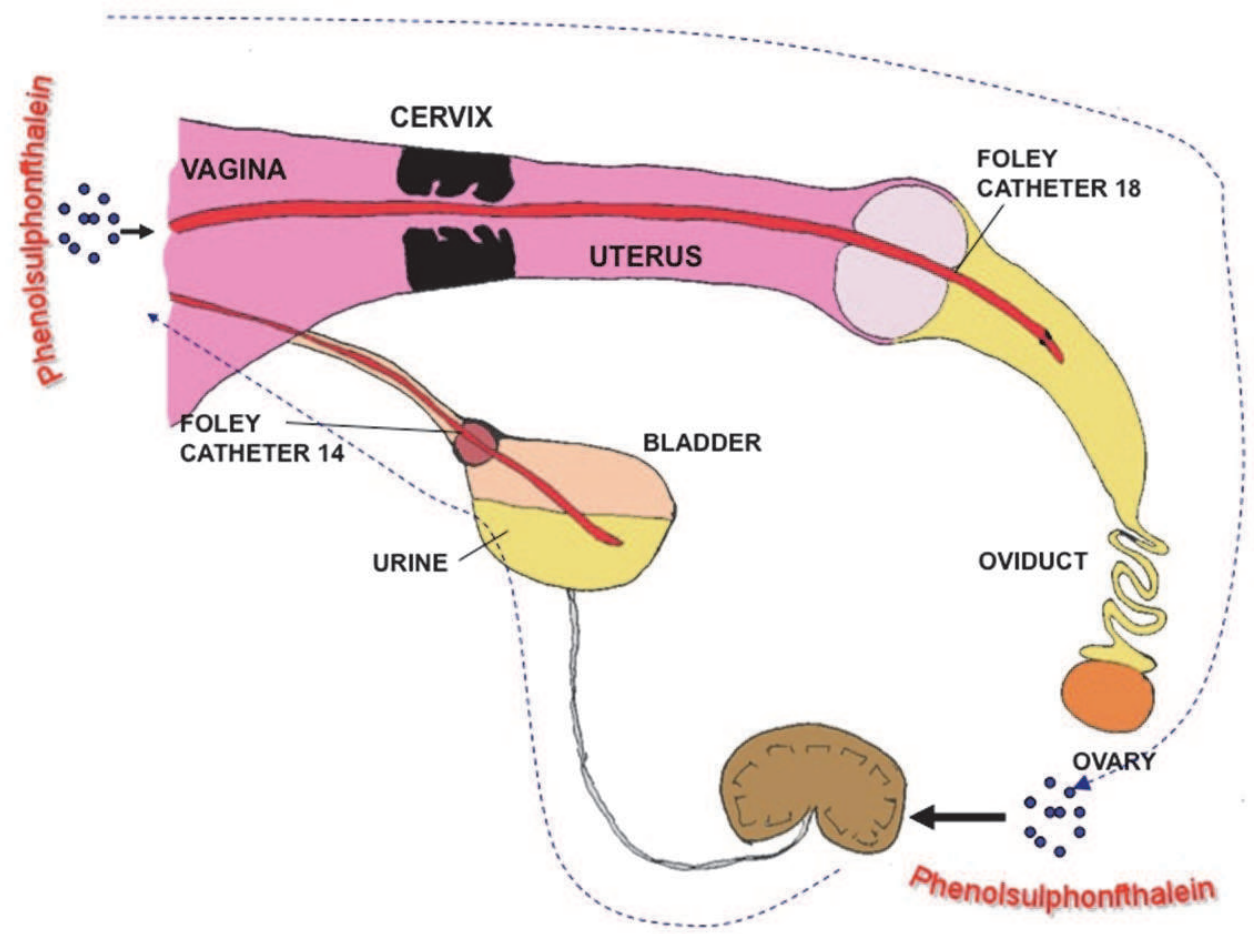

Fig. 5. Phenolsulphonfthalein test to investigate the infertility in cow.

\subsection{Endometrial cytology and uterine bacterial culture}

Numerous pathogens could be localized at the female reproductive tract, affecting the success of fertilization. Infectious diseases could provoke vulvitis, vaginitis, cervicitis or endometritis, and it is interesting to diagnose these disorders. Usually, uterine inflammatory disorders begin with bacterial contamination into the uterine lumen, and continue with adhesion of pathogens to the mucosa, colonization or penetration of the epithelium, and/or release of endotoxins. Uterine inflammation, even in the absence of active bacterial infection, may disrupt embryonic survival and provoke RBC syndrome. The endometrial bacteriological diagnosis is interesting to detect pathogens implicated in infertility. In cattle, especially due to the cervical anatomy, samples can be taken using a catheter connected to a syringe containing $30-60 \mathrm{ml}$ of sterile saline. It is deposited into the uterus and then it is removed and cultured. Clinical or subclinical endometritis could be diagnosed. The sample 
can also be taken by cytology brushes $(65 \mathrm{~cm}, 4 \mathrm{~mm} \varnothing)$ protected by a sterile metal tube (50 $\mathrm{cm}, 5 \mathrm{~mm} \varnothing)$. Endometrial cytology is a practical technique to diagnose subclinical endometritis, when clinical signs are absent. The number of neutrophils indicates the type and grade of endometrial inflammation.

\section{Therapy and control of RBC syndrome to reduce the negative impact on farm profitability}

To reduce the negative effects of repeat breeding on the farm profitability, an effective therapy must be established after a proper diagnosis. Nutritional supplements have been used to restore certain imbalances at herd level. The assisted reproductive techniques, such as in vitro production or embryo transfer, have provided new therapeutic options for resolving this syndrome. Alternative medicines have also developed protocols to overcome the syndrome, as moxibustion or acuapunture. However, hormonal treatments, with progestins, GnRH, exogenous gonadotrophins and prostaglandins, have been traditionally used.

As previously mentioned, RBC syndrome causes considerable economical losses in beef and dairy cattle associated to reproductive failure, drop in milk yield and calves, and treatment cost. Numerous treatments have been studied to solve and prevent this syndrome at herd or individual level.

\subsection{Nutritional treatments}

Nutritional deficiencies have been described as causes of RBC. Diets containing higher concentration of inorganic iodine from 8-12 days before estrus improve the stimulation of the pituitary gland, reducing at the same time the RBC rate (McDonald et al., 1961). Herds with problems of repeated estrus were supplemented with copper and magnesium, minimizing fertility problems (Ingraham et al., 1987). Deficiencies of these minerals have been associated with infertility, anemia or immune suppression. Concentrations of these minerals can be modified in the diet as a result of the season or agriculture practices, or as a consequence of mineral availability alteration associated with some dietary components (e.g. diets containing high level of protein reduce the copper plasma concentration). Betacarotene, precursor of vitamin A, has recently been investigated for its involvement in the formation and function of CL. Although no conclusive results exist, it is suggested that betacarotene improves the progesterone synthesis and reduces the luteal hypofunction (Wang et al., 1988). Further experiments are required in order to assert its therapeutic role or positive effect on reproduction. In 1992, Marai et al. reported that repetitive administration of 40 g/animal/day of sodium phosphate monobasic (in diet) plus 500 ppm zinc (in water) improves the fertility. Deficiencies of phosphorus and zinc are linked to low levels of progesterone, which could be the cause of failures in fertilization or early embryonic death. Other consequences associated with deficient diets are hypoglycemia, reduced coenzyme NAD (important for progesterone synthesis), decreased carbohydrate concentration or increased creatinine. Unsaturated fatty acid diets improve the milk yield and embryo development rates when administered at dry and postpartum periods, also being beneficial in RBCs. 
In conclusion, it is important to consider the nutritional imbalance in RBCs, moreover in dairy cattle with higher nutritional requirements. However, it is not practical to analyze the mineral or chemical composition in blood. It is more reasonable to monitor the food rations in order to avoid disruptions to the reproductive function.

\subsection{Assisted reproduction techniques}

Abnormal implantation and transport of gametes are associated with endometrial defects, resulting in RBC syndrome. Certain assisted reproduction techniques, as in vitro production of embryos or intraperitoneal insemination, have been proposed to solve this syndrome.

Intraperitoneal insemination could be an alternative procedure to the normal deposition of semen in the genital tract of the cow (Lopez-Gatius, 1995). It is considered that between 36 and $89 \%$ of RBCs show uterine diseases but are often difficult to detect in field conditions. A bypass from vagina to peritoneal area (around the ovary) is possible to avoid the negative effects of altered uterine environment on the sperm quality (Figure 6).

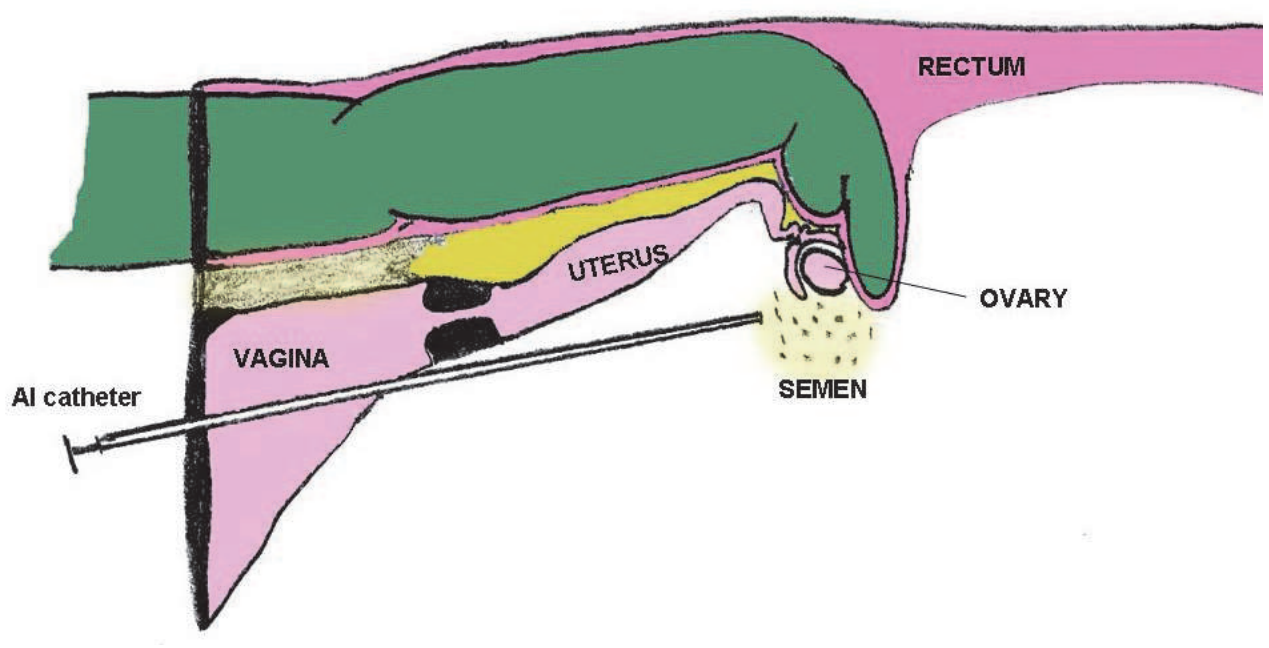

Fig. 6. Intraperitoneal insemination.

Other authors (Tanaka et al., 1994) consider that the majority of embryonic abnormalities occur in the oviducts, but are not apparent until 6-7 days post-breeding. Then, oocytes of RBCs are competent to reach the blastocyst stage. IVM, IVF, IVC and ET techniques are proposed to improve the reproductive success in these animals.

\subsection{Intrauterine treatment}

Disorders related to reproductive tract infections may be related to RBC syndrome and very often overlooked by clinicians. Prophylactic practices have been used, as the uterine administration of antiseptic solutions (lugol) $24 \mathrm{~h}$. after mating/AI (Tanaka et al., 1994), although fertility results are poor (Huszenicsa et al., 1994). 
Studies on bacteriology and histology of the uterus concluded that the non-specific genital infection is one of the main causes of $\mathrm{RBC}$, and it is suggested that antimicrobial treatments (chloramphenicol, gentamicin, enrofloxacin, tetracycline, or nitrofurantine) could improve the reproductive indexes (Santana et al., 1998a).

\subsection{Alternative medicine}

Scientific contributions report the utility of some alternative medicines, such as acupuncture or moxibustion, to reduce the incidence of RBC syndrome.

Moxibustion has been used to reduce reproductive failure in RBCs (Hosaha \& Nakama, 2002). Moxas (balls of about $3 \mathrm{~cm}$ in diameter) containing $2 \mathrm{~g}$ of Artemisia spp. are applied on nine points of the skin and burned for $15 \mathrm{~min}$. The treatments are applied for 3 consecutive days, and then repeated during the heat. Authors describe an increase in blood flow at the uterine arteries, which is considered to improve fertility.

We also find references in the literature about the positive effect of aquapuncture therapy (Lin et al., 2002), i.e. acupuncture combined with injections. A volume of 5-10 ml of glucose $50 \%$ was injected at certain points set by traditional acupuncture in cattle. This study reported a good fertility rate, although many gestations failed later.

\subsection{Hormonal treatments}

Numerous hormonal treatments have been used to improve results in RBCs. The literature about treatments in RBCs is difficult to compile, since criteria to define animals included on this syndrome are variable. It is reported the use of progesterone, alone or combined with other substances, at different times of the estrous cycle to protect the pregnancy and to improve the maternal recognition of pregnancy. Numerous studies describe the influence of $\mathrm{GnRH}$ (and analogues) to improve fertility in RBCs. HCG, an exogenous gonadotrophin, has been administered during luteal phase and at AI time. References exist about the use of pregnant mare serum for the RBC therapy. Prostaglandins have also been widely used to improve heat detection.

\subsubsection{Progesterone $(\mathrm{Pg})$}

Progesterone is essential for implantation and maintenance of pregnancy. CL dysfunction decreases $\mathrm{Pg}$ concentrations and then negatively affects fertility (Gustafsson et al., 1986; Kimura et al., 1987). In contrast, some authors have not found differences between Pg concentrations in normal or repeat breeder cows (Ayalon, 1984).

It has been noted that the administration of progesterone as of 3 to 5 days after insemination and for 2-3 weeks (or more) improves conception rates in RBCs. Umakanthan (1995) administered $250 \mathrm{mg}$ of retard progesterone on days 4, 14, 24, 34, 44 and 54 after insemination. The pregnancy rate was $96 \%$ in RBCs versus $20 \%$ in control cows. Kimura et al. (1987) argue that the delayed formation of the CL induces estrus repetition, and then suggest that progesterone therapy should be started on 4-5th day after insemination.

Bulman \& Lamming (1978) inserted intravaginal devices (PRID) for 14 days in RBCs, previously removing the estrogen capsule. The treatment improved the ovulation and shortened the calving-conception interval. Villaroel et al. (2004) have used this disposal from 
day 5 after AI to day 19. The suggested fertility improvement in RBCs is based on the rise of the progesterone level above the minimum threshold necessary to maintain pregnancy and the increment of progesterone receptors. Intravaginal progestagen treatments are effective some days after the insertion, while progesterone injection (200 $\mathrm{mg}$ on days 5, 7, 9 and 11 post-IA) fails to increase plasma concentrations of progesterone in RBC (Walton et al., 1990).

\subsubsection{GnRH (gonadotrophin-releasing hormone)}

The administration of GnRH around the insemination time aims to accelerate and ensure ovulation in cows, acting directly on the pituitary, stimulating the secretion and release of gonadotrophins, such as LH and FSH, and promoting the preovulatory LH peak, which is essential for follicular dehiscence. In many cases, RBC syndrome is associated with ovulatory defects, as anovulation, delayed ovulation or gonadotrophin release failure.

If luteal deficiency is suspected as reproductive failure in cows, $\mathrm{GnRH}(100 \mu \mathrm{g})$ could be used on day 5 post-AI (Gonzalez-Stagnaro, 1993). GnRH induces LH and FSH discharge pituitary, promotes increased levels of progesterone and exerts a luteoprotector (luteotrophic), increasing fertility in RBCs associated with subfunctional CL or ovulation defects. The mentioned treatment has also been combined with intrauterine antibiotic (infusion of $30-50 \mathrm{ml}$ containing $300000 \mathrm{IU}$ penicillin and 0,5 g streptomycin), increasing fertility in RBCs. This treatment could be more appropriate when abnormal vulvar conformation is present.

A comprehensive study carried out in RBCs indicates that the administration of GnRH at the AI time may be beneficial for improving fertility in these cows (Stevenson et al., 1990). These authors do not recommend the use of double insemination in RBCs, in contrast with Singh et al. (2005) who suggest that pregnancy rates can be improved by increasing the insemination frequency.

\subsubsection{Exogenous gonadotrophin}

These hormones have been used in RBCs to induce ovulation and exert the luteotrophic effect on the CL.

In 1965, Roussel et al. administered intramuscularly pregnant mare serum (PMS) on day 15 or 16 of the estrous cycle, obtaining a conception rate of $73,9 \%$ in RBCs compared with $44,4 \%$ of control cows.

However, HCG is the most used exogenous gonadotrophin for treating RBC syndrome.

Treatment with hCG on day 5 after insemination can achieve higher levels of progesterone for at least 2 weeks, due to the development of accessory CL (Walton et al., 1990)

\subsubsection{Prostaglandins}

The luteolytic effect of prostaglandins has been used to treat RBCs. In this case, treatment aims to achieve better heat detection and to increase the number of cows in heat. Numerous protocols are used in cow, e.g. two PGF2alpha injections apart 11 days and insemination 80 hours later. Intravenous PGF2alpha (0,2 $\mathrm{ml}$ cloprostenol) has also been reported in RBCs at AI time. However, the most frequent use of this hormone has been combined with other 
substances, serving as a pretreatment and with the ultimate goal of improving the reproductive management.

\subsection{Reproductive management improvement}

Treatments are being used recently for fixed-timed artificial insemination, without heat detection. These protocols allow the treatment of cows with silent heats or ovulation problems. Ovsynch is a protocol based on the administration of GnRH, PGF2alpha and GnRH (Pursley et al., 1995) to schedule the insemination time.

It is also essential to improve all aspects related to heat detection, since it has been demonstrated that estrus detection mistakes involve very significant losses in reproduction and production cattle. Therefore, it could be interesting to implement different methods for estrus detection as Kamar or Bovine Heat-beacon devices and pedometers.

\section{References}

Albihn A, Gustafsson H, Hurst M \& Rodriguez-Martinez H. Embryonic ability to prolong the interoestrous interval in virgin and repeat breeder heifers. Anim Reprod Sci 1991;26:193-210.

Almeida AP, Ayalon N \&, Bartoov B. Progesterone Receptors in the endometrium of normal and repeat-breeder cows. Anim Reprod Sci 1987;14:11-19.

Almeida AP. Early embryonic mortality in "repeat-breeder" cows. Ars Veterinaria 1995;11(2):18-34.

Ayalon N. The repeat breeder problem. Procceding $10^{\text {th }}$ International Congress Animal Reproduction and AI. Urbana, III, USA 1984;4:111-141.

Bage R, Gustafsson H, Forsberg M, Larsson B \& Rodriguez-Martinez H. Suprabasal progesterone levels in repeat breeder heifers during the pro- and oestrous period. Theriogenology 1997;47:141.

Bage R. On repeat breeding in dairy heifers. With special focus on follicular dynamics, ovulations, and oocyte quality. SLU, Doctoral thesis 2002.

Bailie JH. Management and economic effects of different levels of oestrus detection in dairy herd. Vet Rec 1982;110:218-221.

Barbato AL, Marqués AP \& Fagundes E. Alteracoes histopatologicas na genitalia de femeas Zebus cruzadas com sindrome "repeat breeder". Rev Bras Reprod Anim 1994;18:3136.

Barlett PC, Kirk JH \& Mather EC. Repeated insemination in Michigan Holstein-Friesian cattle: incidence, descriptive epidemiology and estimated economic impact. Theriogenology 1986;26:309-322.

BonDurant RH, Revah Y, Franti C, Harman RJ, Hird D, Klingborg D, McCloskey M, Weaver L, \& Wilgenberg B. Effect of gonadotrophin-relesing hormone on fertility in repeatbreeder california dairy cows. Theriogenology 1991;35(2):365-373.

Bruyas JF, Fieni F \& Tainturier D. Le syndrome "repeat-breeding": analyse bibliographique $1^{\text {o }}$ partie: Étiologie. Revue med vet 1993;144:385-398. 
Bulman DC \& Lamming GE. Milk progesterone levels in relation to conception, repeat breeding and factors influencing acyclity in dairy cows. J Reprod Fert 1978;54:447458.

Casida LE. Present status of the repeat-breeder cow problem. J Dai Sci 1961;44:2323-2329.

Chaffaux S, Valon F \& Martinez J. Evolution de l'image echographique du produit de conception chez la vache. Bull Acad Vet 1982;55:213-221.

De la Fuente J, Monge A, Cocero MJ \& Barragán C. Evaluación de la mortalidad embrionaria en vacas repetidoras de celos a través de su producción embrionaria. Invest. Agr.: Prod Sanid anim 1988;3(2-3):183-193.

Diskin MG \& Sreenan JM. Fertilization and embryonic mortality rates in beef heifers after artificial insemination. J Reprod Fertil 1980;59:463-468.

Domínguez JC. Fisiopatología puerperal de la vaca. Bovis 1989;29:11-20.

Dovensky T, Popovsky K, Mickousky G, Kocosky Lj, Trojacanec P, Petkov V \& Popovska F. Serum concentration of several biochemical parameters in cows with reproductive disorders. 13 th Intern. Congress on Animal Reprod, Australia 1996.

Duchens M, Forsberg M, Edqvist L, Gustafsson H \& Rodríguez-Martínez H. Effect of induced suprabasal progesterone levels around estrus on plasma concentrations of progesterone, estradiol-17beta and LH in heifers. Theriogenology 1994;42:1159-1169.

Duchens M, Maciel M, Gustafsson H, Forsberg M, Rodríguez-Martínez H \& Edqvist L. Influence of perioestrous suprabasal progesterone levels on cycle length, oestrous behaviour and ovulation in heifers. Anim. Reprod. Sci. 1995;37:95-108.

Duchens M, Rodríguez-Martínez H, Forsberg M \& Gustafsson H. Ultrastructure of bovine ovarian follicles induced to extended growth by perioestrous suprabasal progesterone levels. Acta vet. scand. 1996;37:239-250.

Duffy P, Crowe MA, Austin EJ, Mihm M, Boland MP, Roche JF. The effect of eCG or estradiol at or after norgestomet removal on follicular dynamics, estrus and ovulation in early post-partum beef cows nursing calves. Theriogenology 2004;61:725-734.

Eid LN \& Parrish JJ. Duration of the G2-phase and onset of M-phase during the first cell cycle of the bovine embryo is dependent on bull in vivo fertility. Theriogenology 1995;43:205.

Eid LN, Lorton SP \& Parrish JJ. Paternal influence on S-phase in the first cell cycle of the bovine embryo. Biol Reprod 1994;51:1232-1237.

Erb HN, Smith RD, Oltenacu PA, Guard CL, Hillman RB, Powers PA, Smith MC \& White MA. Path model of reproductive disorders and performance, milk fever, mastitis, milk yield, and culling in Holstein cows. J Dai Sci 1985;68:3337-3349.

Ferreira R, Coelho de Oliveira JF, Antoniazzi AQ, Pimentel CA, Ferrugem JC, Henkes LE, Bordignon V, Dias Gonçalves PB. Relationship between clinical and postmortem evaluation in repeat breeder beef cows. Cienc. Rural 2008; 38

Ferreira R.M., H. Ayres, M.R. Chiaratti, M.L. Ferraz, A.B. Araújo, C.A. Rodrigues, Y.F. Watanabe, A.A. Vireque, D.C. Joaquim, L.C. Smith, F.V. Meirelles, P.S. Baruselli. The low fertility of repeat-breeder cows during summer heat stress is related to a low oocyte competence to develop into blastocysts. J Dai Sci 2011;94:2383-2392. 
Foote RH \& Parks JE. Factors affecting preservation and fertility of bullsperm: a brief review. Reprod Fertil Develop. 1993;5:665-673.

Francos G. The relationships between the incidence of endometritis and repeat breeders in dairy herds. Refuah Veterinarith 1979;36:131-134.

Fulkerson WJ \& Dickens AJ. The effect of season on reproduction in dairy cattle. Australian Vet Journal 1985; 62(11):365-367.

Gonzalez F. Características del comportamiento de los niveles séricos de progesterona y LH en vacas anéstricas. Doctoral thesis, CENSA. La Habana (Cuba), 1981.

González-Stagnaro C, Madrid-Bury N, Morales J \& Marín D. Efecto luteoprotector del tratamiento $\mathrm{GnRH}$ en vacas mestizas repetidoras con cuerpo lúteo sub-funcional. Revista científica FCV-LUZ 1993;1:14-20.

Gustafsson H \& Emanuelson U. Has a repeat breeder cow in the present lactation a higher risk to become a repeat breeder in the next lactation?. 14 th International Congress on Animal Reproduction, Stockholm 2000;(15:26):100.

Gustafsson H, Larsson K, Kindahl H \& Madej A. Sequential endocrine changes and behaviour during oestrus and metoestrus in repeat breeder and virgin heifers. Ani Reprod Sci 1986;10:261-273.

Gwazdauskas FC, Whittier WD, Vinson WE \& Pearson RE. Evaluation of reproductive efficiency of dairy cattle with emphasis on timing of breeding. J Dai Sci 1986,69:290297.

Hartigan PJ, Murphy JA \& Nunn WR. An investigation into the causes of reproductive failure in dairy cows. II.-Uterine infection and endometrial histopathology in clinically normal repeat breeder cows. Irish Vet J 1972;26:245-247.

Harvey D. Nocardia asteroides in the uterus of 2 repeat breeder cows. Canadian Vet J-Revue Vet Canad 1993;34(12):709.

Hewett CD. A survey of the incidence of the repeat breeder cows in Sweden with reference to herd size, season, age and milk yield. British Vet J 1968;124:342-352.

Hodel F, Moll J \& Kunzi N. Factor affecting fertility in cattle. Schweizer Fleckvieh 1995;4:14-24.

Hosaha T \& Nakama S. Effects of moxibustion for reproductive failure in dairy cattle. XXII World Buiatrics Congress, Hannover, Germany 2002, p 212

Humblot P. La mortalité embryonnaire chez les bovins. Colloque de la Societe Francaise pour l'etude de la Fertilite. "Recherches récentes sur l'epidemiologie de la fertilite". Ed. Masson, París, 1986:213-242.

Hunter RHF. Vital aspects of Fallopian tube physiology in pigs. Reprod Dom Anim 2002;37:86-190.

Huszenicza G, Kulcsar M, Nagy P, Mihály K, Fekete S \& Zöldág L. Ovarian and metabolic characteristics of repeat breeding dairy cows and heifers and the effect of intrauterine lugol treatment on their fertility. Proceeding 18th World Buiatrics Congress: 26th Congress of the Italian Association of Buiatrics, Bologna, Italy, August 29-Sept 2, 1994.

Ingraham RH, Kappel LC, Morgan EB \& Srikandakumar A. Correction of subnormal fertility with copper and magnesium supplementation. J. Dairy Sci. 1987;70:167-180 
Kerbler TL, Buhr MM, Jordan LT, Leslie KE \& Walton JS. Relationship between maternal plasma progesterone concentration and interferon-tau synthesis by the conceptus in cattle. Theriogenology 1997;47:703-714.

Kessy BM \& Noakes DE. The use of the starch grain and phenolsulphophthalein test to investigate infertile cows. Vet Rec 1979;105:489-491

Kimura M, Nakao T, Moriyoshi M \& Kawata K. Luteal phase deficiency as a possible cause of repeat breeding in dairy cows. Br. vet. J. 1987;143:560-566.

Lafi SQ \& Kaneene JB. Risk factors and associated economic effects of the repeat breeder syndrome in dairy cattle. Vet. Bull. 1988;58:891-903.

Lagneau F. Infertilite des vaches a chaleurs normales. Rec Méd vét. 1981;157:117-131.

Lamming GE, Darwash AO \& Back HL. Corpus luteum function in dairy cows and embryo mortality. J Reprod Fertil 1989;37(Suppl):245-252.

Lanman JT. Delays during reproduction and their effects on the embryo and fetus. New England J Med 1968;278:993-1092.

Lee CN, Maurice E, Ax RL, Pennington JA, Hoffman WF \& Brown MD. Efficacy of gonadotrophin-releasing hormone administered at the time or artificial insemination of heifers and postpartum and repeat breeder dairy cows. Am J Vet Res 1983;44:2160-2163.

Lewis GS. Uterine health and disorders. J Dai Sci 1997;80:984-994.

Lin JH, Wu LS \& Wu YL. Aquapuncture therapy or repeat breeding in dairy cattle. Am J Chin Medic 2002, 30;2-3:397-404

Linares T, Ploen L, Ekwall H \& Bane A. The ultraestructure of blastocysts collected from virgin and repeat breeder heifers. Nord Vet Med 1984;42:585-598.

Linares T. Embryonic development in repeat breeder and virgin heifers seven days after insemination. Anim. Reprod. Sci. 1982;4:189-198.

Lopez-Gatius F \& Camón-Urgel J. Confirmation of estrus rates by palpation per rectum of genital organs in normal repeat dairy cows. J Vet Med A 1991;38:553-556.

López-Gatius F. Intraperitoneal insemination in repeat-breeder cows: a preliminary report. Theriogenology 1995;44:153-158.

Lotthammer KH. Trastornos de la fertilidad de origen ambiental. In: Infertilidad en la vaca. Ed. Hemisferio Sur. 1988:351-391.

Marai IFM, Daader AH \& El-Darawany AA. Some physiological aspects of repeat breeding in Holstein Friesians and its improvement under Egyptian environment. Beitr trop Landwirtsch vet med 1992;30 (H.2):199-209.

Maurer RR \& Echternkamp SE. Repeat breeder females in beef cattle: influences and causes. J Anim Sci 1985;61(3):624-636.

McClure TJ. Infertilidad nutricional y metabólica de la vaca. Ed. Acribia, Zaragoza, España, 1995.

McDonald RJ, McKay GW \& Thomson JD. The use of organic iodine in treatment of repeat breeder cows. Proceeding of the IVth International Congress on Animal Reproduction 1961:679-681.

Murthy KG, Nanjiah RD \& Keshava MBS. Bacteriological flora of cervical mucus in repeat breeder bovines. Indian Vet J 1974,51:264-268. 
Odde KG. A review of synchronization of estrus in postpartum cattle. J Anim Sci 1990;68:817-830.

Ohtani S \& Okuda K. Histological observation of the endometrium in repeat breeder cows. J Vet Med Sci 1995;2:283-286.

Panangala VS, Fish NA \& Barnum DA. Microflora of the cervico-vaginal mucus of repeatbreeder cows. Can Vet J. 1978,19:83-89.

Payne JM, Rowlands GJ, Manston R \& Dew SM. A statistical appraisal of the results of metabolic profile test on 75 dairy herds. Brit Vet J 1973;129:370-381.

Pedroso R \& Roller F. Problemática de las repeticiones del celo en la hembra bovina. Revisión bibliográfica. Rev Cub Reprod Anim 1996;22(1):1-19.

Perez-Marin CC \& España F. Estrus expression and ovarian function in repeat breeder cows, monitored by ultrasonography and progesterone assay. Reprod Dom Anim 2007; 42, 449-456.

Perry GA, Perry BL. Effect of preovulatory concentrations of estradiol and initiation of standing estrus on uterine $\mathrm{pH}$ in beef cows. Dom Anim Endoc 2008; 34 333-338.

Pierson RA \& Ginther OJ. Ultrasonography of the bovine ovary. Theriogenology 1984;21:495504.

Pieterse MC, Kappen KA, Kruip TAM \& Taverne MAM. Aspiration of bovine oocytes during transvaginal ultrasound scanning of the ovaries. Theriogenology 1988;30:751762.

Pursley JR, Mee MO \& Wiltbank MC. Synchronization of ovulation in dairy cows using PGF2 $\alpha$ and GnRH. Theriogenology 1995;44:915-923.

Quintela, L.A., Becerra, J.J., Pérez-Marín, C.C., Barrio, M., Cainzos, J., Prieto, A., Díaz, C. \& Herradón, P.G. Fetal gender determination by first-trimester ultrasound in dairy cows under routine herd management in Northwest Spain. Anim Reprod Sci 2011 10.1016/j.anireprosci.2011.02.022

Rajamahendran R. Clinical and research applications of real-time ultrasonography in bovine reproduction: A review. Can Vet J 1994;35:563-572.

Reeves JJ, Rantanen NW \& Hauser M. Transrectal real-time ultrasound scanning of the cow reproductive tract. Theriogenology 1984;21:485-494.

Roberts SJ. Veterinary Obstetrics and genital diseases (Theriogenology). Published by the author, Ithaca New York, 1971, 496-506.

Rodriguez LAM, Lozano CB \& Pérez VJE. La translocación robertsoniana 1/29 en ganado vacuno: sus consecuencias en la reproducción. Salud Públ .Nutrición 2000, 2.

Roine K \& Saloniemi H. Incidence of infertility in dairy cattle. Acta Vet Scand 1971;19:354367.

Roussel JD, Stallcup OT, Rakes JM \& Ward RF. Treatment of repeat breeders with pregnant mare serum. J Dai Sci 1965;48:808.

Sagartz JW \& Hardenbrook HJ. A clinical, bacteriologic and histologic survey of infertile cows. J Amer Vet Med Assc 1971;158:619-622.

Santana AO, Oba E, Langoni H \& Uribe-Velasquez LF. Avalia $\square$ ao bacteriologica do endometrio em femeas bovinas repetidoras de cio. Arch Reprod Ani 1998;6;62-71.

Santana AO, Oba E, Lopes J \& Uribe-Velasquez LF. Avalia $\square$ ao histopatologica do endometrio em femeas bovinas repetidoras de cio. Arch Reprod Ani 1998;6;58-61. 
Santana AO, Oba E, Ramos AA \& Uribe-Velasquez LF. Concentracao serica de FSH, LH, Estradiol e Progesterona P4 em femeas bovinas repetidoras de cio. Arch Reprod Ani, 2000;12:26-32.

Sheldon M. Bovine fertility-practical implications of the maternal recognition of pregnancy. In practice 1997;Nov-Dec:546-556.

Shrestha HK, Nakao T, Higaki T, Suzuki T \& Akita M. Resumption of postpartum ovarian cyclicity in high-producing Holstein cows. Theriogenology. 2004 Feb;61(4):637-49.

Singh B, Savavia F, Bage R \& Rodríguez-Martinez H. Pregnancy rates in repeat-breeder heifers following multiple artificial inseminations during spontaneous oestrus. Acta Vet Scand 2005;46:1-12.

Singla VK, Singh G \& Dwived PN. In vivo evaluation of drug sensitivity pattern of bacterial isolates in repeat breeders cows. Indian J Anim 1993;4:425-426.

Staigmiller RB \& England BC. Folliculogenesis in the bovine. Theriogenology 1982;17:43-52.

Stevenson JS, Call EP \& Scoby RK. Double insemination and gonadotropin-releasing hormone treatment of repeat-breeding dairy cattle. J Dai Sci 1990;73:1766-1772.

Stock AE \& Fortune JE. Ovarian follicular dominance in cattle: relationship between prolonged growth of the ovulatory follicle and endocrine parameters. Endocrinology 1993;132:1108-1114.

Swanson LV \& Young AJ. Failure of gonadotripin-releasing hormone or human chorionic gonadotropin to enhance the fertility of repeat-breeder cows when administered at the time of insemination. Theriogenology 1990; 34(5):955-963.

Tanaka H, Hishinuma M, Takahashi Y \& Kanagawa H. Developmental competence of oocytes from the ovaries of repeat-breeding cows after in vitro fertlization. $J$ Vet Med Sci 1994;56(3):547-548.

Thibier M, Gouffe D, Jean O, Valognes J, Daunizeau A \& Humblot P. Enhancing the rate recovery and quality of the embryos in repeat breeding cows by using a GnRH analogue injection at mid-luteal phase prior to breeding. Theriogenology 1985;24(6):725-733.

Umakanthan T. A field trial on progesterone treatment in repeat breeding cows. Ind Vet J 1995;72:1308.

Vasconcelos JLM, Chande CG \& Silva AV. Microorganismos isolados de material uterino de vacas e sua sensibilidade "in vitro" aos antiioticos, nas bacias leiteiras de passos (MG) e Sao Jose dos Campos (SP). In: Congresso Brasileiro de Reproducao Animal, Belo Horizonte, 1995;11:438.

Villaroel A, Martino A, BonDurant RH, Deletang F \& Sischo WM. Effect of postinsemination supplementation with PRID on pregnancy in repeat-breeder Holstein cows. Theriogenology 2004;61:1513-1520

Wahome JN, Stuart MJ, Snuth AE, Hearne WR \& Fuquay JW. Insemination management for a one-injection PGF $2 \alpha$ synchronization regimen. II.One versus two inseminations following detection estrus. Theriogenology 1985;24:501.

Waldmann A, Reksen O, Landsverk K, Ropstad E, Kommisrud E, Dahl E \& Refdal AO. Progesterone at first insemination-effects on non-return and repeat-breeding. $14^{\text {th }}$ International Congress on Animal Reproduction, Stockholm 2000;(15:13):87. 
Walton JS, Halbert GW, Robinson NA \& eslie KE. Effects of progesterone and human chorionic gonadotrophin administration five days potsinsemination on plasma and milk concentrations of progesterone and pregnancy rates of normal and repeat breeder dairy cows. Can J Vet Res 1990;54:305-308

Wang JY, Owen FG \& Larson LL. Effect of beta-carotene supplementation on reproductive performance of lactating Holstein cows. J.Dairy Sci. 1988;71:181-186.

Zemjanis R. "Repeat-breeding" or conception failure in cattle. In: Current Therapy in Theriogenology. Ed. D.A.Morrow, Philadelphia, WB Saunders, 1980:205-213.

Zemjanis, R. The problem of repeat breeding in cattle, New England Vet. Meeting, 1963. 


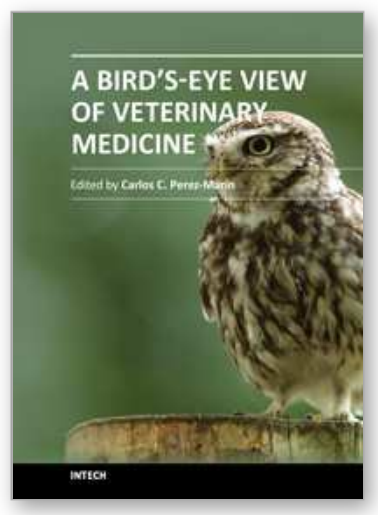

\author{
A Bird's-Eye View of Veterinary Medicine \\ Edited by Dr. Carlos C. Perez-Marin
}

ISBN 978-953-51-0031-7

Hard cover, 626 pages

Publisher InTech

Published online 22, February, 2012

Published in print edition February, 2012

Veterinary medicine is advancing at a very rapid pace, particularly given the breadth of the discipline. This book examines new developments covering a wide range of issues from health and welfare in livestock, pets, and wild animals to public health supervision and biomedical research. As well as containing reviews offering fresh insight into specific issues, this book includes a selection of scientific articles which help to chart the advance of this science. The book is divided into several sections. The opening chapters cover the veterinary profession and veterinary science in general, while later chapters look at specific aspects of applied veterinary medicine in pets and in livestock. Finally, research papers are grouped by specialisms with a view to exploring progress in areas such as organ transplantation, therapeutic use of natural substances, and the use of new diagnostic techniques for disease control. This book was produced during World Veterinary Year 2011, which marked the 250th anniversary of the veterinary profession. It provides a fittingly concise and enjoyable overview of the whole science of veterinary medicine.

\title{
How to reference
}

In order to correctly reference this scholarly work, feel free to copy and paste the following:

Carlos C. Perez-Marin, Laura Molina Moreno and Guillermo Vizuete Calero (2012). Clinical Approach to the Repeat Breeder Cow Syndrome, A Bird's-Eye View of Veterinary Medicine, Dr. Carlos C. Perez-Marin (Ed.), ISBN: 978-953-51-0031-7, InTech, Available from: http://www.intechopen.com/books/a-bird-s-eye-view-ofveterinary-medicine/clinical-approach-to-the-repeat-breeder-cow-syndrome

\section{INTECH}

open science | open minds

\section{InTech Europe}

University Campus STeP Ri

Slavka Krautzeka 83/A

51000 Rijeka, Croatia

Phone: +385 (51) 770447

Fax: +385 (51) 686166

www.intechopen.com

\section{InTech China}

Unit 405, Office Block, Hotel Equatorial Shanghai

No.65, Yan An Road (West), Shanghai, 200040, China

中国上海市延安西路65号上海国际贵都大饭店办公楼405单元

Phone: +86-21-62489820

Fax: $+86-21-62489821$ 
(C) 2012 The Author(s). Licensee IntechOpen. This is an open access article distributed under the terms of the Creative Commons Attribution 3.0 License, which permits unrestricted use, distribution, and reproduction in any medium, provided the original work is properly cited. 